\title{
SPINAL CORD LESIONS AND LOWER EXTREMITY BRACING: AN OVERVIEW AND FOLLOW-UP STUDY
}

\author{
By Rose Mikelberg, B.Sc.P.T. and Sheila Reid, B.Sc.P.T. \\ Rehabilitation Institute of Montreal, 6300 Darlington Avenue, Montreal, Quebec, Canada.
}

\begin{abstract}
This study was undertaken to illustrate to what extent spinal cord injury patients use their lower extremity braces upon leaving the rehabilitation setting. A questionnaire was sent to 60 people, all of whom had had braces prescribed from the Rehabilitation Institute of Montreal, in the 5-year-period between 1973-77. All had been discharged from the rehabilitation centre for at least I year. Thirty-five replies were received. The majority (6o per cent) continued to use their wheelchair as their main means of displacement. Thirty-one per cent did not use their braces at all. Most people tended to use their braces at home only for standing and exercise. The authors therefore believe that more careful study should be given to each individual case before braces are prescribed. Alternatives to bracing should be strongly considered. A review of the literature is included.
\end{abstract}

\section{Introduction}

THE use of lower extremity bracing to facilitate ambulation in the spinal cord injured patient is a topic not dealt with extensively. (Munro, I950; Munro, I954; Machek, I955; Kaplan, I966; Ebel, I968; Hahn, I974; Rossman, 1974; Coghlan, 1977; Natvig, 1978.) Since 1960, only six studies exist in the literature. As clinicians in the field of physical medicine, we are familiar with the time, effort and great cost involved in fitting and training these patients with leg braces. Follow-up studies done since 1950 are not numerous and those that exist do not go into depth concerning the reasons for use or non-use of the braces (Munro, I950; Munro, I954; Machek, I955; Kaplan, I966; Ebel, I968; Hahn, I974; Rossman, I974; Coghlan, I977; Natvig 1978).

The following is an up-to-date presentation showing the use being made of these braces once patients leave the rehabilitation setting and discussing the efficacy of bracing spinal cord injured patients.

Questionnaires were sent to all spinal cord injured patients who received braces from the Rehabilitation Institute of Montreal in the 5-year period from 1973-77 inclusive. The replies were tabulated and compared to the relatively few available previous studies of this kind.

\section{History}

In a review of the literature since 1950, certain trends are apparent. In the earlier years, as centres for spinal cord injured patients were being established, ambulation was often not considered a viable alternative (Abramson, 1949; Dinken, I95I; Gordon, 1956; Kaplan, 1966).

There are no generally accepted criteria for prescribing leg braces for patients who are considered candidates for ambulation, and there is a lack of follow-up 
studies determining how often these braces are used once the patients have left the rehabilitation centre.

It is agreed that the upright position holds physiological advantages for the patient. These include: (I) preventing osteoporosis and subsequent fractures of the long bones of the lower extremities; (2) decreasing the formation of urinary calculi; (3) decreasing spacticity; (4) aiding digestion; (5) preventing ischial decubiti. (Abramson, I949; Dinken, I95I; Ebel, I968; Jackson, I97I; Hahn, I974; Silber et al., 1975; Natvig et al., 1976.) The patients' self-image may also be improved with standing. (Antler et al., 1969.) Braces enable some individuals to overcome architectural barriers such as stairs or narrow doorways. (Munro, 1954; Natvig et al., I976.) Bracing and subsequent ambulation may also affect the patients' ability to become re-employed. (Munro, I954.)

Varied criteria have been used to determine whether patients were suitable candidates for braces. (Abramson, 1949; Dinken, I951; Gordon, 1956; Kaplan, I966; Edberg 1967; Ebel, I968; Stauffer, I97I; Hussay, I97I ; Coghlan 1977.) Briefly the prescription of lower extremity braces and subsequent ambulation was advocated for younger, well-motivated patients with lesions below the level of Thoracic I2. This did not, however, preclude the prescription of braces for use in standing, as a general beneficial exercise, for patients above the level of Thoracic $I 2$. This philosophy is loosely adhered to at the centre where this study was carried out.

Few follow-up studies have been conducted to determine the use made of leg braces once the patients have left the rehabilitation centre. (Munro, I950; Munro, I954; Machek, I955; Kaplan, I966; Ebel, I968; Hahn, I974; Rossman, 1974; Coglan, I977; Natvig, 1978.)

In summary, the studies reviewed showed that less than 50 per cent of the patients continued to use their leg braces after discharge from the rehabilitation setting; less than half of the 50 per cent continued to use them functionally; the others used them mainly for standing or limited walking. It is important to note that many of these studies were conducted at the time of discharge only.

When the level of the lesion was noted, most of the patients who used their braces functionally were found to be those with incomplete or cauda equina injuries. In lesions higher than Thoracic I2, long leg braces were considered limiting factors in functional ability. (Dinken, I95 I ; Gordon, I956; Jackson, I97 I ; Kaplan et al., 1973; Hussey et al., 1973; Rossman et al., 1974.) Other factors affecting and limiting the use of braces included age (Dinken, I95I; Gordon, I956), general health status (Dinken, I95I), adequacy of bracing (Dinken, I95 I; Ebel, I968), high energy consumption (Ebel, I968; Gordon I956), discomfort and/or difficulty of use (Kaplan, 1973), inability to perform activities of daily living (Kaplan, 1973), motivation (Ebel, 1968; Edberg, 1967), contractures (Edberg, 1967), spasticity (Edberg, 1967), decreased sensation in the lower extremities (Edberg, 1967), and decreased proprioception (Hussey, I973).

\section{Materials and Methods}

All the spinal cord injured patients who received braces from the Rehabilitation Institute of Montreal in the 5-year period from 1973-77 were contacted by mail. The patients included in the study had been discharged from the centre for at least I year. This time period was chosen to allow for a more accurate evaluation of use in the home setting.

Only spinal cord injured patients, I5 years of age and older were included in order to eliminate as many variables as possible. Although the exclusion of these 
younger persons may cause an unfavourable slant in the final analysis of our data, we nevertheless decided to deal only with the 'adults' in our eligible population because these patients are generally in good health except for problems directly related to the injury. The onset of this injury is usually abrupt, therefore accommodation to the braces since childhood is not a factor.

As part of the pilot study, a questionnaire was sent to the $3 \mathrm{I}$ patients who received braces in 1976 and 1977 . Twenty replies were received. Subsequently a revised questionnaire was sent to these $3 \mathrm{I}$ patients and as well, to those patients who received braces in 1975, 1974 and 1973 .

In total, 60 questionnaires were sent out. Thirty-five were returned with replies; five were returned unopened.

The classification of these patients is outlined in Table I.

\section{TABLE I}

\section{Classification of patients}

Group A: I8 patients had two long leg braces

3 patients had one long leg brace and one short leg brace.

Group B: I4 patients had one or two short leg braces (including one who no longer needed his one short leg brace).

\section{Level of Lesion}

Group A: 4 were complete lesions from $\mathrm{T}_{5}-\mathrm{T}_{7}$ with no abdominals

8 were complete lesions at TI2-LI with abdominals in varying strengths

9 were incomplete lesions from $\mathrm{C}_{7}$ to cauda equina (including three with one long leg brace and one short leg brace).

Group B: I4 were incomplete lesions from $\mathrm{C}_{5}$ to cauda equina.

\section{Age}

The age varied from I 6 to 74 years, with the majority (26/35) falling between 20 and 40 years of age.

\section{Sex}

There were seven females and 28 males.

TABLE II

Main means of Displacement

Group A: 86\% wheelchair

$9 \%$ wheelchair

$5 \%$ braces.

Group B: $24 \%$ wheelchair

$38 \%$ wheelchair and braces

$38 \%$ braces.

Group A and 5 together:

$60 \%$ wheelchair

$20 \%$ wheelchair and braces

I $7 \%$ braces

$3 \%$ no longer using braces (henceforth not considered in tabulation of results). 


\section{Results}

Table II summarises the patients' main means of displacement.

Table III summarises the frequency of use of the braces.

Table IV indicates the percentage of patients actually using their braces.

\section{TABLE III}

Frequency of use

\section{Group A}

(main means of displacement: wheelchair)

$$
55 \% \text { not using braces at all }
$$

$28 \%$ using three times per week or more

I $7 \%$ using less than three times per week.

Group A

(main means of displacement: wheelchair and braces)

Group A

braces used daily for limited time only.

(main means of displacement: braces) braces worn daily.

\section{Group B}

(main means of displacement: wheelchair)

one person not using braces at all

one person used braces on a weekly basis

one person used braces three times per week, 15 minutes at a time.

Group B

(main means of displacement: wheelchair and braces)

braces worn daily (at home only).

Group B

(main means of displacement: braces)

braces worn daily.

\section{TABLE IV}

Use or non-use

Group A: $45 \%$ were not using their braces at all

$47 \%$ were using them in varying degrees

$5 \%$ were using them at all times.

Group B: $8 \%$ were not using their braces at all

$54 \%$ were using them in varying degrees

$38 \%$ were using them at all times.

\section{Discussion}

For those whose main means of displacement is the wheelchair and braces, the braces were being used daily for architectural barriers etc., as these people were working outside the home.

From Group B, those who used their wheelchair and braces as their main 
means of displacement, wore the braces every day, but used them in the home environment only. Even those who only used their braces tended to remain in the home.

Essentially the patient with paralysed abdominal muscle does not use his braces. The majority of users have incomplete or cauda equina lesions.

For Group A, the most commonly stated reasons for use were: the psychological factors of being upright, architectural barriers, general exercise, and standing. These reasons were mentioned with equal frequency. Others stated were: improvement of bladder and bowel function and improvement of circulation.

For Group B, general exercise and architectural barriers were the reasons most commonly mentioned for use. Improved circulation and standing were also mentioned.

By far the most commonly given reason for abandoning the braces for Group A was that it was 'too difficult and time consuming'. Many people also found there was a lack of suitable space in the home environment for proper use. Sores, illness, weight change, poor adjustment and winter weather were also mentioned.

For Group B, there was no overwhelming cause given in this group. Weight change, poor adjustment, and fractures were cited.

Eighty-six per cent of all those who replied to the questionnaire had had 80 per cent or more of the cost of their braces defrayed. Of all those questioned, 80 per cent said it was worth the time and effort and that they would have paid for the braces themselves. Twenty per cent however, said that they would not have paid for the braces themselves or that it was not worth the time and effort.

The authors were interested in whether readmission on an in-patient or outpatient basis (for gait training only) had had an influence on the continued use of the braces. Overall it seems to have had no effect.

\section{Conclusions}

Considering the relatively high degree of non-use or non-functional use of the braces (only 5 per cent Group A, 38 per cent Group B were using them at all times), it would seem that more care and consideration should be given to each individual case before braces are prescribed. The rehabilitation team, including a qualified orthotist, should be in agreement as to the prescription of the braces. Factors to be considered are: specific need, the motivation of the patient, the age and physical condition of the patient (including at least the presence of complete abdominals and no fixed deformities), and where applicable, financing of the braces.

From the authors' observation and experience, the prescription of braces on first admission should be questioned. An alternative would be to send the patient home to maximise his function and independence in a wheelchair. Further evaluation and the possibility of readmission could then be discussed at a regular follow-up visit.

Since many of those using their long leg braces do so mainly for standing, and as the fitting and construction of braces is a lengthy and costly procedure, it might do just as well to equip these patients with alternative aids to standing. There are many standing devices on the market at present. These range from pneumatic orthesis (Silber et al., 1975), to parapodiums (Priest, 1974), to aids to stand from a wheelchair (Mahoney, I95I), to standing frames (Kay, I973), to mechanical tilt tables (Climo, I964), and others (Eagleson et al., 1966; Kim, 
I968). Although these devices cannot be used for ambulation, they do present the patient with the opportunity to assume the upright position and thereby reap the benefits of weight bearing on the long bones of the lower extremity.

\section{SUMMARY}

Almost half (I I/35 or 3 I per cent) of all those questioned (including those with short leg braces) do not use their braces at all. Of those who do, very few are for functional ambulation.

Therefore in view of the man-hours and money spent on bracing the spinal cord injured patient, more careful consideration should be given to the decision to prescribe braces in each individual case.

\section{RÉSUMÉ}

Une étude a été éffectuée pour determiner jusqu'à quel point les blessés medullaires utilisent leurs orthèses de membre inferieur après avoir quitté le centre de réadaptation. Un questionnaire fut envoyé à 60 personnes qui avaient tous reçus des ortheses de l'Institut de Réadaptation de Montreal pour la period 1973-77 inclusivement. Tous ces gens avaient terminé leurs réadaptation depuis au moins un an. Trente-cinq réponses ont été reçues. La majorité $(60 \%)$ utilisait la chaise roulante comme moyen principal de d'éplacement. Trente-et-un pour-cent n'utilisaient pas du tout leurs orthèses. La plupart ne se servait des orthèses qu'à la maison pour la station debout et comme exercice. Les auteurs croient donc qu'on devrait étudier de plus près chaque cas individuellement avant de préscrie les orthèses, et selon le cas, les appareils autre que les orthèses conventionnels pourraient être considerés. Une revue de la litérature est inclus.

\section{ZUSAMMENFASSUNG}

Diese Studie will zeigen, wie weit Patienten mit Wirbelsäule Wchäden nach ihrer Rehabilitierung von Beinschienen Gebrauch machen. Ein Fragebogen wurde an 60 Personen gerichtet, denen das Rehabilitierungsinstitut $\mathrm{zu}$ Montreal das Tragen von Beinschienen vorgenschrieben hatte. Ihre Rehabilitierung fand in den Jahren zwischen I973 and 1977 statt. Jeder Patient hatte das Institut ein Jahr vorher verlassen. Wir erhielten 35 Antworten. Die Mehrheit (60\%) benutzten den Fahrstuhl als ihr hauptsächliches Bewegungsmittel. 31\% machten gar keinen Gebrauch von ihren Beinschienen. Die meisten Patienten machten nur zu Hause von ihren Beinschienen Gebrauch-wenn sie standen oder an ihren Ubungen arbeiteten. Diese Ermittlungen zeigen, dass jeder Fall vor der Verschreibung von Beinschienen mit grösserer Sorgfalt studiert werden sollmit besonderer Berücksichtung von Alternativen. Literaturnachweis ist beigeschlossen.

Acknowledgements. We wish to acknowledge the invaluable assistance and support of Ms Jane Boucher, Charge Physiotherapist at the Rehabilitation Institute of Montreal. The project was carried out under the auspices of the Research Department of the Rehabilitation Institute of Montreal.

\section{REFERENCES}

Abramson, A. S. (1949). Principles of bracing in rehabilitation of paraplegia. Bull. Hosp. Foint Dis., 10, I75-182 (Oct).

Antler, L., Lee, M. H. M., Zaretsky, H. J. H., Peznick, D. P. \& Halberstam, J. L. (1969). Attitude of rehabilitation patients towards the wheelchair. F. Psychol., 73, 45-52 (Sept).

Bulletin of Prothetics Research, (1976). Veterans Administration Prothetics Centre Research Report. 214-27I.

Climo, S. (I964). Erect position as an aid in the care of paraplegic; use mechanical aid (tilt-table). Plast. and Reconst. Surg., 13, 65-69. 
Coghlan, J. K., Robinson, C. E., Nerwmarch, B. J. \& Jackson, G. (I977). Paraplegia: a follow-up functional review. B. C. Med. Fournal, 19, 10.

Covalt, D. A. (1956). Rehabilitation of the paraplegic patient. F.A.M.A., I208-1209.

Dinken, H. (I95I). Physical treatment and rehabilitation of paraplegic patient. F.A.M.A., I46, 232-234.

Eagleson, H. M. Jr., Craig, R. E., Best, E. E. \& Knudson, A. B. C. (I966). A specially mobile standing device (surfboard) for spinal cord injury patients. Proc. Ann. Div. Spinal Cord Inj., Conf., 15, 29-36.

EBEL, A. (1968). Restorative management of paraplegic patient: philosophy and concept of bracing. N.Y.F. of Med., 68, 2037-2040.

EDBERG, E. (1967). Paralytic Disfunction IV. Bracing for patients with traumatic paraplegia. Phys. Ther., 47, 88-123.

GoRDON, E. E. (1956). Physiological approach to ambulation in paraplegia. F.A.M.A., I61, 686-688.

HAHN, H. R. (1974). Lower extremity bracing in paraplegics with usage follow-up. Paraplegia, 8, I47-I53.

HusSEY, A. W. \& STAUFFER, E. S. (1973). Spinal cord injury. Requirements for ambulation. Arch. Phys. Med. Rehab., 54, 544-547.

JACKSON, R. R. (I97I). Do you recommend long leg braces for patients with paraplegia? If so what type of bracing do you prefer? Phys. Ther., 5I, 823.

JEBSON, R. H. (1967). Use and abuse of ambulation aids. F.A.M.A., 199, 5-10.

Kaplan, L. I., Grynbaum, B. B., Rusk, H. A. \& AnASTASIa, T. (I973). A reappraisal of braces and other mechanical aids in patients with spinal cord dysfunction: Results of a follow-up study. Arch. Phys. Med., 47, 393-406.

KAY, R. H. (1973). A Standing frame for paraplegics and tetraplegics. Physiotherapy, 59, 223.

KIM, K. H. (1968). The Kim Self Stander for wheelchair patients (A self help device), Arch. Phys. Med., 42, 599-601.

KENT, H. (1958). Results in spinal cord injuries with early physical medicine and rehabilitation. F. of Oklahoma State Med. Ass., 5I, 7.

MACHEK, O. \& Collins, H. A. (I955). Should the paraplegic be braced? Missouri Med., 52, I90-I92.

Mahoney, F. E. \& Goode, Q. W. (I95I). Standing device for paraplegic patients. Arch. Phys. Med., 32, 465-468.

MunRo, D. (1950). Two year end results in total rehabilitation of vet. with spinal cord and cauda equina injuries. New Eng. F. of Med., 242, 9-16.

MunRo, D. (1954). Rehabilitation of patients totally paralysed below waist with special reference to making them ambulatory and capable of earning their own livings. New Eng. F. of Med., 250, 4-I4.

Olson, Kelly, P. (I973). Mat walker for paraplegic rehabilitation. Phys. Ther., 58, 38-39.

NATIVIQ, H. \& McADAM, R. (1976). Ambulation without wheelchairs for paraplegics with complete lesions. Paraplegia, 16, I42-146.

PASLEY, A. (1974). Ambulation programme for patients with thoracic spinal cord lesions. Phys. Ther., 54, 372-375.

Preist, M. T. (1974). Parapoduim for adult paraplegics, Bull. Prosthet. Res., 39I-403.

Rosman, N. \& SPIRA, E. (I974). Paraplegic use of walking braces: A survey. Arch. Phys. Med. Rehab., 55, 310-314.

Rusk, H. A. (1958). Rehabilitation of the severe paralytic. Postgrad. M., 23, 616-623.

Silber, M., ChUng, T., VARghese, G., Hinterbuchner, C., Bailey, M. \& Hivry, N. (I975). Pneumatic orthesis: pilot study. Arch. Phys. Med. Rehabil., 56, 27-32.

STAUFFER, E. S. (I97I). Do you recommend Long leg braces for patients with paraplegia? If so, what type of bracing do you prefer? Phys. Ther., 5I, 824.

Symington, D. \& FordYCE, W. E. (I965). Changing concepts in the management of traumatic paraplegia. G. P., I4I-I 55.

Warren, C. G., Lehman, J. F. \& Delateur, B. J. (I975). Pelvic band use in orthotics for adult paraplegic patients, Arch. Phys. Med. Rehab., 56(5) 22 I-223.

Zankek, H. T., Sulton, B. B. \& BuRney, T. E. (I954). Paraplegic programme under physical med. and rehabilitation. One year's experience. 